\title{
THE INTERACTION BETWEEN MERCURY(II) AND SULFATHIAZOLE
}

\author{
Sebastián Bellú, Estela Hure, Marcela Trapé and Marcela Rizzotto* \\ Área Química Inorgánica, Universidad Nacional de Rosario, Suipacha 531, 2000 Rosario - Argentina \\ Emma Sutich \\ Departamento de Microbiología, Universidad Nacional de Rosario, Suipacha 531, 2000 Rosario - Argentina \\ Mirna Sigrist \\ Facultad de Ingeniería Química, Universidad Nacional del Litoral, Santiago del Estero 2829, 3000 Santa Fe - Argentina \\ Virtudes Moreno \\ Departamento de Química Inorgánica, Universidad de Barcelona, Diagonal 647, Barcelona - Spain
}

Recebido em 4/3/02; aceito em 14/10/02

\begin{abstract}
The interaction of mercury(II) with sulfathiazole has been analyzed. IR and NMR spectral studies suggest a coordination of $\mathrm{Hg}$ (II) with the $\mathrm{N}_{\text {thiazolic }}$ atom, unlike related $\mathrm{Hg}$-sulfadrugs compounds. The complex was screened for its activity against Escherichia coli, showing an appreciable antimicrobial activity compared with the ligand.
\end{abstract}

Keywords: mercury complexes; sulfonamides; sulfonamide metal complexes.

\section{INTRODUCTION}

The synthesis of metal sulfanilamide compounds has received much attention due to the fact that sulfanilamides were the first effective chemotherapeutic agents to be employed for the prevention and cure of bacterial infections in humans ${ }^{1,2}$. Furthermore, sulfadrugs and their metal complexes, possess many applications as diuretic, antiglaucoma or antiepileptic drugs, among others ${ }^{3-8}$. The sulfanilamides exert their antibacterial action by the competitive inhibition of the enzyme dihydropterase synthetase towards the substrate $p$-aminobenzoate ${ }^{9}$. Several authors have reported the antimicrobial activity of sulfanilamides and their metal complexes ${ }^{10,11}$. Studies on their metal chelates could have much physiological and pharmacological relevance because the metal chelates of sulfadrugs have been found to be more bacteriostatic than the drugs themselves ${ }^{12}$. Sulfathiazole, [4-amino- $N$-2-thiazolylbencenosulfonamide], (Figure 1 ), is clinically one of the most used ${ }^{11}$. Besides, $\mathrm{Hg}$ (II) has been used in medicine for many years ${ }^{13,14}$. Although the synthesis of metal complexes of sulfathiazole has been reported, the structural determination is often incomplete and conflicting ${ }^{10}$. Casanova et al. ${ }^{10}$ reported the first crystal structure of a $\mathrm{Zn}$-sulfathiazole complex, where the drug acts as a bridging ligand through both the $\mathrm{N}_{\text {amino }}$ and $\mathrm{N}_{\text {thiazole }}$ atoms. On the other hand, coordination behavior of metal ions as $\mathrm{Zn}$ (II) and $\mathrm{Cd}(\mathrm{II})$ with sulfadrugs showed different from $\mathrm{Hg}$ (II) ones ${ }^{9}$. Considering the different behavior of sulfathiazole as ligand and $\mathrm{Hg}(\mathrm{II})$ as metal ion from another $d^{10}$ metal ions, a comparative study of the interaction between sulfathiazole and $\mathrm{Hg}$ (II) must be of interest. As part of a research program devoted to the investigation of the structural and physicochemical properties of metal complexes of chemoterapeutic agents, in the present paper we report synthesis, spectral and microbiological studies of the mercury-sulfathiazole complex (Hg-ST). In order to compare, we also report the studies we have done with the mercury-sulfanilamide complex (Hg-SA) at the same time.

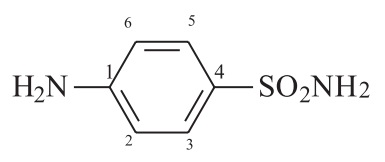

Sulfanilamide (SA)

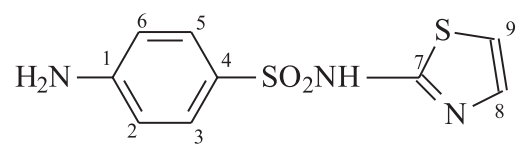

Sulfathiazole (HST)

Figure 1. Notation used for sulfathiazole, sulfanilamide and their derivatives in this paper

\section{EXPERIMENTAL PART}

Caution: $\mathrm{Hg}$ (II) compounds are toxic ${ }^{13}$. Appropriate precautions should be taken to avoid skin and digestive contacts ${ }^{15}$.

\section{Synthesis of complexes: general procedure}

Aqueous solution of mercuric chloride $(1 \mathrm{mmol} / 10 \mathrm{~mL})$ was added dropwise to a stirred aqueous solution of the corresponding sulfonamide: sulfathiazole as sodium salt; and sulfanilamide in alkaline medium, given by the minimum amount of sodium hydroxide $0.1 \mathrm{M}$ necessary to dissolve the drug $(2 \mathrm{mmol} / 20 \mathrm{~mL})^{16}$. Immediately, the resulting mixture became white, because a white precipitate was formed. Then, the reaction mixture was left to stand at RT, protected from the light. After two days the precipitate was centrifuged, washed with water several times and dried under vacuum, protected from the light.

When the molar ratio [ligand]/[metal] was major than $2 / 1$, only the same compounds were obtained. 


\section{Analysis and physical measurements}

The content of $\mathrm{Hg}$ was determined by atomic absorption spectroscopy with a Perkin Elmer spectrometer, model 3110 with a flux injection system Fias 100 Perkin Elmer, in the laboratory of Analytical Services, UNL.

Elemental chemical analyses were performed in a microanalyser C.E. Instruments, model Eager 1108, at the Barcelona University (UB).

Infrared spectra in the solid state were carried out in the 4000$500 \mathrm{~cm}^{-1}$ range on a Nicolet 520-FTIR spectrophotometer (UB), and on a Perkin Elmer-337 spectrophotometer (UNR), using both the $\mathrm{KBr}$ pellets technique.

Electronic spectra were recorded between 200 and $800 \mathrm{~nm}$ in a Jasco model 530 double beam spectrophotometer, using quartz cells of $1 \mathrm{~cm}$ path length, at RT and in the following solvents: water, hydrochloric acid $1 \mathrm{M}$, sodium hydroxide $1 \mathrm{M}$, ethanol 96\%. DMSO was not employed for recording these spectra because the window of this solvent is not useful for wavelength below $250 \mathrm{~nm}$.

The ${ }^{1} \mathrm{H}$ NMR spectra in DMSO- $d_{6}$ were performed on a Bruker Unity-300 spectrometer (UB) and on a Bruker AC-200 E (UNR) at $25{ }^{\circ} \mathrm{C} .{ }^{13} \mathrm{C}\left\{{ }^{1} \mathrm{H}\right\}$ NMR spectra in deuteraded dimethyl sulfoxide, $\left(\mathrm{CD}_{3}\right)_{2} \mathrm{SO}$, (DMSO- $d_{6}$ ) were obtained on a Bruker Unity-300 spectrometer, using high-power proton decoupling, pulse sequence: s2pul. Proton and carbon chemical shifts in DMSO- $d_{6}$ were referenced to DMSO- $d_{6}\left({ }^{1} \mathrm{H} \mathrm{NMR}, \delta_{(\mathrm{DMSO})}=2.49 \mathrm{ppm} ;{ }^{13} \mathrm{C} \mathrm{NMR}, \delta_{(\mathrm{DMSO})}=39.5\right.$ ppm).

The conductivity of saturated aqueous solutions were measured at room temperature on a Horiba B-173 Conductivity Meter. These measurements suggested a nonelectrolytic nature for $\mathrm{Hg}$-ST.

Spectrofluorometry analyses were recorded in a Aminco Bowman, for SA and $\mathrm{Hg}$-SA in $\mathrm{HCl} 0.1 \mathrm{M}$, at $25{ }^{\circ} \mathrm{C}$; excitation wavelength: $262 \mathrm{~nm}$; emission range: $280-420 \mathrm{~nm}$. There were no changes neither in shape nor position of the peak of SA $(341 \mathrm{~nm})$ respect to $\mathrm{Hg}$-SA, which indicates that the coordination of $\mathrm{Hg}$ (II) with SA does not affect directly the benzene ring ${ }^{17}$. HST and Hg-ST were not active in the same conditions.

\section{Antimicrobial tests: Minimum inhibitory concentration (MIC) determination}

MIC of the compounds against bacterial strains obtained from the American Type Culture Collection (ATCC) and from a Centennial Hospital's patient at the University of Rosario, were performed at the Laboratory of Microbiology -at the Biochemical Faculty, University of Rosario-, by the microdilution method following the National Committee for Clinical Laboratory Standard (NCCLS) specifications ${ }^{18}$. Briefly: $1 \mathrm{~mL}$ of bacterial suspension in the last phase of growth was inoculated in $1 \mathrm{~mL}$ of Mueller Hinton Broth (Difco) containing the compounds at a final concentration ranging from 64 to $0.12 \mu \mathrm{g} / \mathrm{mL}$ derived from serial 2-fold dilutions. The final inoculum was approximately $1 \times 10^{5}$ viable bacteria/ $\mathrm{mL}$ and the final volume, $2 \mathrm{~mL}$. Inoculated tubes were incubated at $35^{\circ} \mathrm{C}$ for $18-21 \mathrm{hs}$. Readings were made visually (by observed turbidity). The MIC was defined as the lowest concentration of antimicrobial agent showing complete inhibition of growth. MIC of the reference drugs (sulfathiazole -sodium salt- and sulfanilamide, both obtained from Sigma) were compared with those of the test compounds. Drug- and bacterial-free controls were included.

The complexes ( $0.0128 \mathrm{~g}$ of each one) were dissolved using the minimum amount of $\mathrm{HCl} 1 \mathrm{M}$ for a final volume of $10 \mathrm{~mL}$ of aqueous solution $[\mathrm{pH}=5(\mathrm{Hg}-\mathrm{SA}, \mathrm{SA})$ and $3(\mathrm{Hg}-\mathrm{ST}, \mathrm{NaST})]$. The same treatment was employed for the corresponding ligand (sulfathiazole or sulfanilamide). The solvent was used for further dilutions and tested as blank experiments.

\section{RESULTS AND DISCUSSION}

\section{General physicochemical characteristics of the complexes}

It was not possible to obtain crystals in order to analyze the metallic complexes structure by single-crystal XRD technique. The main difficulty to obtain suitable crystals is their poor solubility in water and in the most of the organic solvents. Thus, the spectroscopic techniques are an alternative to infer about the molecular structure. Conclusions about the structure of the complexes under study were obtained from NMR, IR and electronic spectra.

In water, the solubility at RT was $0.69 \mathrm{mg} / 100 \mathrm{~mL}$ for $\mathrm{Hg}-\mathrm{ST}$ and $1.05 \mathrm{mg} / 100 \mathrm{~mL}$ for $\mathrm{Hg}-\mathrm{SA}$. The solubility was enhanced by $\mathrm{HCl} 1 \mathrm{M}$ for both complexes: $0.450 \mathrm{~g} / 100 \mathrm{~mL}$ for $\mathrm{Hg}-\mathrm{ST}$, and 1.84 $\mathrm{g} / 100 \mathrm{~mL}$ for $\mathrm{Hg}-\mathrm{SA}$. $\mathrm{NaOH}$ dissolved the Hg-ST compound, but not the Hg-SA one.

Presence of $\mathrm{Hg}(\mathrm{II})$ in both complexes was tested by reaction with $\mathrm{KI}^{19}$. Absence of $\mathrm{Cl}^{-}$and $\mathrm{Na}^{+}$in both complexes was tested by the Vohlard method ${ }^{20}$ and using a flame spectrophotometer Metrolab305, respectively. Elemental analyses gave satisfactory results for $\mathrm{Hg}$ (sulfanilamidato), in the case of $\mathrm{Hg}-\mathrm{SA}$ complex and for $\left.\mathrm{Hg}[\text { (sulfathiazolato })_{2}(\mathrm{OH})_{2}\right]$ in the case of the $\mathrm{Hg}$-ST one.

$\mathrm{Hg}$ (sulfanilamidato $)_{2}$ : white solid $(61.8 \%$ yield). Found (calculated for $\mathrm{C}_{12} \mathrm{H}_{14} \mathrm{~N}_{4} \mathrm{~S}_{2} \mathrm{O}_{4} \mathrm{Hg}$ ): C, 27.5 (26.6) ; H, 3.2 (2.6); N, 10.4 (10.3); S, 11.2 (11.8); Hg, 37.4 (36.9).

$\mathrm{Hg}$ [(sulfathiazolato $\left.)_{2}(\mathrm{OH})_{2}\right]$ : white solid (99.4\% yield). Found (calculated for $\mathrm{C}_{18} \mathrm{H}_{20} \mathrm{~N}_{6} \mathrm{~S}_{4} \mathrm{O}_{6} \mathrm{Hg}$ ): C, 30.3 (29.0); $\mathrm{H}, 2.5$ (2.7); N, 11.5 (11.3); S, 17.3 (17.2); Hg: 26.3 (26.9).

The anhydrous character of both compounds was confirmed by thermal analyses between 100 and $120^{\circ} \mathrm{C}$ at the Barcelona University.

\section{NMR spectra}

${ }^{1} \mathrm{H}$ and ${ }^{13} \mathrm{C}$ of the complexes sulfa- $\mathrm{Hg}$ and the respective ligands are presented in Tables 1-3. In order to make an accurate assignment of the signals to the corresponding resonances ${ }^{21}$, we have also recorded the ${ }^{1} \mathrm{H}$ and ${ }^{13} \mathrm{C}$ NMR DMSO- $d_{6}$ solutions of SA, HST and its sodium salt $(\mathrm{NaST})$.

\section{Hg-SA complex}

The proton spectrum of DMSO- $d_{6}$ solution of the Hg-SA complex showed signals at 7.37, 6.52, 6.86 and $5.52 \mathrm{ppm}$ (Table 1). All signals of the complex shifted to low frequencies compared with those of the ligand, and the most affected one was the peak of the protons of the $-\mathrm{SO}_{2} \mathrm{NH}_{2}$ (amide group), integrated for only one ${ }^{1} \mathrm{H}$. This fact could be a consequence of the coordination with the $\mathrm{Hg}$ (II).

Table 1. ${ }^{1} \mathrm{H}$ NMR shift assignments of sulfanilamide (SA) and its $\mathrm{Hg}(\mathrm{II})$ complex $(\mathrm{Hg}-\mathrm{SA})$ in DMSO- $d_{6}{ }^{\mathrm{a}}(\delta, \mathrm{ppm})$

\begin{tabular}{lccc}
\hline Assignment & $\mathrm{SA}$ & $\mathrm{Hg}-\mathrm{SA}$ & $\Delta \delta(\mathrm{ppm})^{\mathrm{b}}$ \\
\hline $\mathrm{C}(3)-\mathrm{H} / \mathrm{C}(5)-\mathrm{H}$ & 7.28 & 7.37 & +0.09 \\
$\mathrm{C}(2)-\mathrm{H} / \mathrm{C}(6)-\mathrm{H}$ & 6.41 & 6.52 & +0.11 \\
$\mathbf{S O}_{2}-\mathrm{NH}_{2}$ & 6.64 & 6.86 & $\mathbf{+ 0 . 2 2}$ \\
$-\mathrm{NH}_{2}$ & 5.39 & 5.52 & +0.13 \\
\hline
\end{tabular}

${ }^{a}$ Relative to TMS with DMSO- $d_{6}$ peak as reference $\left({ }^{1} \mathrm{H}, 2.49 \mathrm{ppm}\right)$

b $\Delta \delta=\delta$ (sulfonamide complex) - $\delta$ (sulfonamide) 


\section{Hg-ST complex}

${ }^{1} \mathrm{H}$ and ${ }^{13} \mathrm{C}$ NMR of the complex $\mathrm{Hg}$-ST are presented in Tables 2 and 3.

García-Raso et al founded that $\mathrm{Hg}$ (sulfamidato) ${ }_{2}$ complexes (sulfamidato corresponds to one of the following ligands: sulfadimethoxine, sulfamethoxypyridazine, sulfadiazine, sulfamerazine, sulfadimidine and sulfamethoxazole) presented a similar NMR pattern, with two equivalent sulfonamide groups ${ }^{9}$. In these compounds, upon complexation, a downfield shift (+1.0 to +4.0 ppm) was observed for the carbon directly bonded to the sulfonamidic nitrogen. No proton resonance was observed for the amidic group in the $\mathrm{H}^{1} \mathrm{NMR}$ of these complexes in any case ${ }^{9}$.

In our case, on the contrary, one of the most significative difference between the ${ }^{1} \mathrm{H}$ NMR spectra of DMSO- $d_{6}$ solutions of $\mathrm{NaST}$ (the ligand) and $\mathrm{Hg}-\mathrm{ST}$ was a new signal that could be assigned to the amidic proton (7.04 ppm in the $\mathrm{Hg}$-ST spectrum). This signal was absent in the ${ }^{1} \mathrm{H}$ NMR spectrum of the employed ligand (NaST) in the same conditions.

The ${ }^{13} \mathrm{C}$ NMR of DMSO- $d_{6}$ solutions of $\mathrm{Hg}-\mathrm{ST}$ showed resonances at $151.97[\mathrm{C}(7)], 151.84[\mathrm{C}(1)], 128.24[\mathrm{C}(8)], 127.77$ [C(4)], $127.68[\mathrm{C}(3) / \mathrm{C}(5)], 112.34[\mathrm{C}(2) / \mathrm{C}(6)], 107.35[\mathrm{C}(9)]$ ppm (Table 3 ). The most affected signals, compared with the HST ones, were those of $\mathrm{C}(7)$ and $\mathrm{C}(8)$, both belonging to the thiazole ring.

There are at least two very important differences between the ${ }^{13} \mathrm{C}$ NMR spectrum of the $\mathrm{Hg}$ (II)-sulfadrugs compounds coordinated by the sulfonamidic nitrogen ${ }^{9}$ and the $\mathrm{Hg}$-ST compound reported in the present work: first: the large shielding observed for $\mathrm{C}(7)$ and the large deshielding observed for $\mathrm{C}(8)$; second: only a very little shift for the carbon directly bonded to the sulfonamidic group, both in the ${ }^{13} \mathrm{C}$ NMR spectrum of $\mathrm{Hg}-\mathrm{ST}$. These results suggest that the coordination of HST with $\mathrm{Hg}$ (II) would not be by the sulfonamidic nitrogen, but probably by the $\mathrm{N}_{\text {thiazolic }}$. Anyway, it is not possible to discard at all the participation of the amidic nitrogen in the mercury coordination with sulfathiazole.
IR spectra

The analyses of the IR spectra of the sulfadrugs and its metal complexes have been one of the most used techniques applied to the knowledge of the interaction between the metal ions and the donor atoms of these molecules ${ }^{10}$.

IR selected spectral data of the sulfa- $\mathrm{Hg}$ complexes and the respective ligands are presented in Tables 4 and 5.

\section{Participation of the amino group}

The bands that appeared near 3500 and $3400 \mathrm{~cm}^{-1}$ due to $v_{\text {asym }}\left(\mathrm{NH}_{2}\right)$ and $v_{\text {sym }}\left(\mathrm{NH}_{2}\right)$ vibrations of the $\mathrm{NH}_{2}$ group were modified with respect to those of the free respective ligands. For the Hg-SA and $\mathrm{Hg}$-ST compounds, these vibration modes appeared at higher (Hg-ST) and lower (Hg-SA) wavenumbers, compared with those of the free ligand. It has been proposed that the difference between the $v^{*}\left(\mathrm{NH}_{2}\right)$ of silver-sulfadrugs compounds and those of the parent ligands, being $v^{*}\left(\mathrm{NH}_{2}\right)=v_{\mathrm{s}}+v_{\text {as }} / 2$, gives information about the involvement of the $\mathrm{NH}_{2}$ group in the silver complexation ${ }^{10}$. According to this, if the value of $v^{*}$ free ligand $-v^{*}$ coordinated ligand is $\geq 70$, the amino moiety is involved in the coordination. Casanova et $\mathrm{al}^{10}$ founded that the IR spectrum of $\mathrm{Zn}(\mathrm{ST})_{2} \cdot \mathrm{H}_{2} \mathrm{O}$ showed $v(\mathrm{~N}-\mathrm{H})$ stretching vibrations at 3480 and $3390 \mathrm{~cm}^{-1}$, shifted to higher frequencies with respect to the equivalent ones in the uncoordinated ligand (3320 and $\left.3280 \mathrm{~cm}^{-1}\right)$. This fact was interpreted, with regard to the crystal structure of the $\mathrm{Zn}$ (II) complex, as indicative of the coordination of the $\mathrm{NH}_{2}$ group. However, this parameter as a measure of the coordination of the amino group must be taken into account carefully ${ }^{11}$, because when the amino $\mathrm{N}$ atom does not interact directly with the metal ion, it is possible that these modifications would be consequently due to the hydrogen bonds involving the amino group ${ }^{9,22}$.

\section{Hg-SA complex}

The bands due to $v_{\text {asym }}\left(\mathrm{NH}_{2}\right)$ and $v_{\text {sym }}\left(\mathrm{NH}_{2}\right)$ vibrations of the $\mathrm{NH}_{2}$

Table 2. ${ }^{1} \mathrm{H}$ NMR shift assignments of sulfathiazole (HST), its sodium salt (NaST) and its $\mathrm{Hg}(\mathrm{II})$ complex $(\mathrm{Hg}-\mathrm{ST})$ in $\mathrm{DMSO}-d_{6}^{\mathrm{a}}(\delta$, ppm)

\begin{tabular}{|c|c|c|c|c|c|}
\hline Assignment & HST & $\mathrm{NaST}$ & $\Delta \delta(\mathrm{ppm})^{\mathrm{b}}$ & $\mathrm{Hg}-\mathrm{ST}$ & $\Delta \delta(\mathrm{ppm})^{\mathrm{c}}$ \\
\hline $\mathrm{SO}_{2}$-NH- & 12.34 & - & - & 7.04 & -5.30 \\
\hline $\mathrm{C}(3)-\mathrm{H} / \mathrm{C}(5)-\mathrm{H}$ & 7.45 & 7.42 & -0.03 & 7.45 & 0.00 \\
\hline $\mathrm{C}(9)-\mathrm{H}$ & 7.18 & 6.91 & -0.27 & 7.19 & +0.01 \\
\hline $\mathrm{C}(8)-\mathrm{H}$ & 6.74 & 6.41 & -0.33 & 6.68 & -0.06 \\
\hline $\mathrm{C}(2)-\mathrm{H} / \mathrm{C}(6)-\mathrm{H}$ & 6.58 & 6.48 & -0.10 & 6.54 & -0.04 \\
\hline$-\mathrm{NH}_{2}$ & 5.79 & 5.47 & -0.32 & 5.76 & -0.03 \\
\hline
\end{tabular}

${ }^{\mathrm{a}}$ Relative to TMS with DMSO- $d_{6}$ peak as reference $\left({ }^{1} \mathrm{H}, 2.49 \mathrm{ppm}\right) ;{ }^{\mathrm{b}} \Delta \delta=\delta(\mathrm{NaST})-\delta(\mathrm{HST}) ;{ }^{\mathrm{c}} \Delta \delta=\delta(\mathrm{Hg}-\mathrm{ST})-\delta(\mathrm{HST})$

Table 3. ${ }^{13} \mathrm{C}$ NMR shift assignments of sulfathiazole (HST), its sodium salt (NaST) and its $\mathrm{Hg}(\mathrm{II})$ complex $(\mathrm{Hg}-\mathrm{ST})$ in DMSO- $d_{6}^{\text {a }}(\delta$, ppm)

\begin{tabular}{|c|c|c|c|c|c|}
\hline Assignment & HST & $\mathrm{NaST}$ & $\Delta \delta(\mathrm{ppm})^{\mathrm{b}}$ & ST-Hg & $\Delta \delta(\mathrm{ppm})^{\mathrm{c}}$ \\
\hline $\mathrm{C}(7)$ & 167.90 & 170.30 & +2.40 & 151.97 & -15.93 \\
\hline $\mathrm{C}(1)$ & 152.18 & 150.47 & -1.71 & 151.84 & -0.34 \\
\hline $\mathrm{C}(4)$ & 127.86 & 132.13 & +4.27 & 127.77 & -0.09 \\
\hline $\mathrm{C}(3) / \mathrm{C}(5)$ & 127.69 & 127.84 & +0.15 & 127.68 & -0.01 \\
\hline $\mathrm{C}(8)$ & 124.24 & 137.18 & +12.94 & 128.24 & +4.00 \\
\hline $\mathrm{C}(2) / \mathrm{C}(6)$ & 112.42 & 112.26 & -0.16 & 112.34 & -0.08 \\
\hline $\mathrm{C}(9)$ & 107.42 & 106.81 & -0.61 & 107.35 & -0.07 \\
\hline
\end{tabular}

${ }^{\text {a }}$ Relative to TMS with DMSO- $d_{6}$ peak as reference $\left({ }^{13} \mathrm{C}, 39.5 \mathrm{ppm}\right) ;{ }^{\mathrm{b}} \Delta \delta=\delta(\mathrm{NaST})-\delta(\mathrm{HST}) ;{ }^{\mathrm{c}} \Delta \delta=\delta(\mathrm{Hg}-\mathrm{ST})-\delta(\mathrm{HST})$ 
group appeared at lower frequencies than in the free ligand. The sharp and intense bands at 1319 and $1153 \mathrm{~cm}^{-1}$, which were assigned to the asymmetric and symmetric $v\left(\mathrm{SO}_{2}\right)$ modes, respectively ${ }^{23}$, shifted both to lower frequencies. The band at $697 \mathrm{~cm}$ ${ }^{1}$ in the SA infrared spectrum (attributed to the $\left.v(\mathrm{~S}-\mathrm{N})^{24}\right)$, was shifted to $670 \mathrm{~cm}^{-1}$ in the IR spectrum of the $\mathrm{Hg}$-SA complex.

Table 4. Assignment of the vibrational spectra (frequency: $v, \mathrm{~cm}^{-1}$ ) of sulfanilamide (SA) and its $\mathrm{Hg}(\mathrm{II})$ complex (Hg-SA)

\begin{tabular}{lccc}
\hline Assignment & $\mathrm{SA}$ & $\mathrm{Hg}-\mathrm{SA}$ & $\Delta v\left(\mathrm{~cm}^{-1}\right)^{*}$ \\
\hline$-\mathrm{NH}_{2}$ (sym) & 3380 & 3335 & -55 \\
$-\mathrm{NH}_{2}$ (asym) & 3482 & 3420 & -62 \\
$-\mathrm{SO}_{2}$ (asym) & 1319 & 1223 & -96 \\
$-\mathrm{SO}_{2}$ ( sym) & 1153 & 1115 & -38 \\
$\mathrm{RSO}_{2} \mathrm{~S}-\mathrm{N}$ & 697 & 670 & -27 \\
\hline
\end{tabular}

$* \Delta v=v$ (sulfonamide complex) - $v$ (sulfonamide)

\section{Hg-ST complex}

The bands due to $v_{\text {asym }}\left(\mathrm{NH}_{2}\right)$ and $v_{\text {sym }}\left(\mathrm{NH}_{2}\right)$ vibrations of the $\mathrm{NH}_{2}$ group appeared at higher frequencies than in the free ligand. The frequency $v(\mathrm{~N}-\mathrm{H})$ of the sulfonamido group ${ }^{24}$, which in the IR spectrum of HST was founded at $3210 \mathrm{~cm}^{-1}$, in the $\mathrm{Hg}$-ST one appeared at $3233 \mathrm{~cm}^{-1}$.

The sharp and intense bands at 1330 and $1140 \mathrm{~cm}^{-1}$ were assigned to the asymmetric and symmetric $v\left(\mathrm{SO}_{2}\right)$ modes, respectively ${ }^{23}$. These energies were not shifted with respect to those of the ligand, suggesting no interaction of the $-\mathrm{SO}_{2}$-group with the metal ion.

The strong band at $1540 \mathrm{~cm}^{-1}$, attributed in the sulfadrug to the stretching $\mathrm{C}=\mathrm{N}$ thiazole ring vibration, was shifted to lower frequencies, appearing at $1485 \mathrm{~cm}^{-1}$ in the IR of the complex. This fact is in agreement with the interaction through the $\mathrm{N}_{\text {thiazole }}$ atom ${ }^{25}$. The band at $660 \mathrm{~cm}^{-1}$ in the IR spectrum of $\mathrm{Hg}-\mathrm{ST}$ can be attributed to the $v(\mathrm{C}-\mathrm{S})$ vibrations (thiazole ring mode $)^{25}$, shifted to higher frequency (in the IR spectrum of HST, appeared at $635 \mathrm{~cm}^{-1}$ ).

Table 5. Assignment of the vibrational spectra (frequency: $v, \mathrm{~cm}^{-1}$ ) of sulfathiazole (HST) and its $\mathrm{Hg}$ (II) complex (Hg-ST)

\begin{tabular}{lccc}
\hline Assignment & HST & Hg-ST & $\Delta v\left(\mathrm{~cm}^{-1}\right)^{*}$ \\
\hline$-\mathrm{SO}_{2} \mathrm{~N}-\mathrm{H}$ amide & 3210 & 3233 & +23 \\
$-\mathrm{NH}_{2}$ (sym) & 3260 & 3378 & +118 \\
$-\mathrm{NH}_{2}$ (asym) & 3320 & 3461 & +141 \\
$-\mathrm{SO}_{2}$ - (asym) & 1330 & 1326 & -4 \\
$-\mathrm{SO}_{2}$ (sym) & 1140 & 1139 & -1 \\
$\mathrm{RSO}_{2} \mathrm{~S}-\mathrm{N}$ & 690 & 697 & +7 \\
Thiazole ring modes & & & \\
$\mathrm{C}=\mathrm{N}$ & 1540 & 1485 & -55 \\
$\mathrm{C}-\mathrm{S}$ & 635 & 660 & +25 \\
\hline
\end{tabular}

$* \Delta v=v$ (sulfonamide complex) - $v$ (sulfonamide)

\section{Electronic spectra}

\section{Hg-SA complex}

The electronic spectrum of SA in water showed one band with the absorption maximum at $259 \mathrm{~nm}$, which was shifted in $\mathrm{HCl} 1 \mathrm{M}$ to $217 \mathrm{~nm}$. The same absorbance maximum was observed for aqueous solution of $\mathrm{Hg}$-SA (259 nm), which was shifted to $224 \mathrm{~nm}$ in $\mathrm{HCl} 1$ M. The band observed in the electronic spectrum of SA could be assimilated to the allowed $\mathrm{E}$ band $\left(\pi \longrightarrow \pi^{*}\right)$ in the aniline, at 230 $\mathrm{nm}$, which shifts to lower wavelength in acidic media (203 nm for the protonated aniline $)^{26}$. Similar shift was observed in the UV-Vis spectrum of the Hg-SA complex, suggesting a similar behavior than the SA one. This fact could imply no metal coordination with the amino group, which would be free to accept a proton.

\section{Hg-ST complex}

In water, the electronic spectrum of HST (as sodium salt) showed two bands, with absorbance maxima at 259 and at $283 \mathrm{~nm}$. In $\mathrm{HCl}$ $1 \mathrm{M}$ these absorption maxima shifted to 217 and $280 \mathrm{~nm}$ respectively.

Aqueous solution of the Hg-ST complex showed two bands too, with absorbance maxima at practically the same wavelength (260 and $283 \mathrm{~nm}$ ). These maxima were shifted to lower wavelength in $\mathrm{HCl} 1 \mathrm{M}$ (222 and $279 \mathrm{~nm}$ respectively), similarly as it could be observed with $\mathrm{Hg}-\mathrm{SA}$.

These facts were in agreement with the observations of NMR and IR spectra, and with the facts that both complexes were dissolved by $\mathrm{HCl}$, suggesting that the amino group would be free in both compounds.

\section{The coordination chemistry of mercury(II)}

A diversity of coordination numbers for mercury complexes can be found. In monoorganomercury(II) compounds, the primary bonds leave the $\mathrm{Hg}$ atom with enough residual acidity for it to be able to reach a coordination number of seven when the donor atoms forming the secondary bonds are small. Besides, the tendency of $\mathrm{Hg}$ to be involved in inter- or intramolecular secondary interactions results in there being only a small number of $\mathrm{Hg}$ complexes with coordination number two $^{27}$. On the other hand, $\mathrm{Hg}$ (II), which has an extremely high affinity for thiol-containing compounds, forms 1:2 metal:ligand linear complexes with them ${ }^{28}$.

Tetrahedral geometry were postulated in mercury(II) complexes of the type $\mathrm{HgX}_{2} \mathrm{~L}_{2}$ ( $\mathrm{L}=1,3$-imidazole-2-thione, 1-methyl-1,3imidazole-2-thione; $\left.\mathrm{X}=\mathrm{Cl}^{-}, \mathrm{Br}-\right)$ on the basis of IR and $\mathrm{NMR}$ data ${ }^{29}$. In the complex of $\mathrm{Hg}$ (II) with 2-( $\alpha$-hydroxybenzyl)thiamine the metal coordination unit consists of two distorted tetrahedra sharing two vertexes, and the high basicity of the $\mathrm{N}$ of the pyrimidine ring allows the coordination with the metal ${ }^{30}$. An example of octahedral local geometry is the complex of $\mathrm{Hg}$ (II) with the bidentate ligand lactobionic acid (L): $\left[\mathrm{HgL}_{2}\right] \cdot 2 \mathrm{H}_{2} \mathrm{O}^{31}$.

With respect to $\mathrm{Hg}(\mathrm{II})$-sulfadrugs complexes, both local geometries (linear arrangement ${ }^{9}$ and tetrahedral ${ }^{13}$ ) were founded by X-ray crystal structure.

\section{Sulfathiazole conformation}

It is known that sulfathiazole posseses at least five crystalline or polymorphic forms: I, II, III, IV and $\mathrm{V}^{32}$. The main difference between them being in the types of hydrogen bonds present. Although both amido and imido forms are possible for the sulfathiazole molecule, the sulfathiazole exists in the solid state in the imido form. In the $\mathrm{Zn}$ sulfathiazole complex, as a result of the deprotonation and coordination with the metal via the $\mathrm{N}_{\text {thiazole }}$, the sulfadrug in the complex adopts an intermediate form between the imido and the amido ${ }^{10}$.

In our case, we propose that the local geometry around the $\mathrm{Hg}$ atom would be linear for $\mathrm{Hg}-\mathrm{SA}$ ( $\mathrm{Hg}$ bounded to two $\mathrm{N}_{\text {amido }}$ atoms) and tetrahedral for $\mathrm{Hg}-\mathrm{ST}$ ( $\mathrm{Hg}$ bonded to two $\mathrm{N}_{\text {thiazole }}$ atoms and to two $\mathrm{O}_{\text {hydroxyl }}$ atoms). 
Anyway, on the basis of all these measurements, no definite molecular formulation for the $\mathrm{Hg}-\mathrm{St}$ and $\mathrm{Hg}$-SA compounds can be inferred. Other studies might be made (e.g. EXAFS, extended X-ray absorption fine structure) in order to confirm the molecular structures.

\section{Antibacterial studies}

Some metal complexes of sulfadrugs promote rapid healing of skin disorders (e.g. the $\mathrm{Ag}(\mathrm{I})$-sulfadiazine complex is used for human burnt treatment, and the $\mathrm{Zn}$ (II)-sulfadiazine, in preventing bacterial infection in burnt animals ${ }^{13}$. Cobalt(II), Nickel(II) and Copper(II) complexes of sulfacetamide were screened for their activity against E. coli and S. aureus, showing an appreciable antimicrobial activity compared with the ligands ${ }^{3}$. Copper(II), zinc(II) and cadmium(II) complexes of trimethoprim (which is not a sulfadrug but it is used within sulfametoxazole, a sulfadrug) were screened for their activity against several bacteria (E. coli ATCC 25922; E. aerogenes ATCC 134048; E. cloacae ATCC 13047; K. pneumoniae ATCC 13883; S. marcescens ATCC 8100; $C$. freundii ATCC8090; S. flexneri ATCC 12022; P. bulgaris ATCC 13315; P. morganii NCTC 235; P. aeruginosa ATCC 9721; P. aeruginosa ATCC 27853; A. calcoaceticus ATCC 19606; S. aerus ATCC25923) showing activity similar to that of trimethoprim ${ }^{22}$.

Sulfadrugs are among the drugs of first election (together with ampicilin, gentamicin and trimethoprim-sulfametoxasol) as chemotherapeutic agents in bacterial infections by $E$. coli in humans ${ }^{33}$. In the present work, the antibacterial activity of the $\mathrm{Hg}$ (II)-sulfadrugs complexes obtained and the corresponding ligand was evaluated against both Escherichia coli ATCC 25922 and an Escherichia coli obtained from a Centennial Hospital's patient at Rosario University (Table 6).

Table 6. Minimal inhibitory concentration (MIC, $\mu \mathrm{g} / \mathrm{ml}$ ) of the drugs for E. coli ATCC 25922 and Escherichia coli obtained from a patient of the Centennial Hospital from Rosario University

\begin{tabular}{lcc}
\hline sulfadrug & $\begin{array}{c}\text { MIC, } \mu \mathrm{g} / \mathrm{ml}, \\
\text { for } \text { E. coli } \\
\text { ATCC } 25922\end{array}$ & $\begin{array}{c}\text { MIC, } \mu \mathrm{g} / \mathrm{ml}, \\
\text { for E. coli from } \\
\text { Centennial Hospital }\end{array}$ \\
\hline sulfanilamide & $>128$ & $>128$ \\
Hg-SA & 64 & 8 \\
$\begin{array}{l}\text { sulfathiazole } \\
\text { (sodium salt) }\end{array}$ & $>128$ & $>128$ \\
Hg-ST & 16 & 8 \\
\hline
\end{tabular}

Hg-SA and Hg-ST presented similar antibacterial activity against the assayed E. coli, and their MIC values were lower than the corresponding ligands in the same conditions. The activity of both complexes was better against the E. coli from the Hospital's patient than against the ATCC 25922 one.

\section{CONCLUSION}

The results obtained allow us to suggest that the amidic nitrogen would be the responsible for the coordination of $\mathrm{Hg}$ (II) with sulfanilamide, while the coordination of $\mathrm{Hg}$ (II) with sulfathiazole would be different from the common pattern observed in related compounds ${ }^{9}$, that is, the coordination between $\mathrm{Hg}(\mathrm{II})$ and sulfathiazole would be through the $\mathrm{N}_{\text {thiazolic }}$, with two hydroxyl groups bonding to the $\mathrm{Hg}$ atom, in a local tetrahedral geometry.

The microbiological results imply that the metal complexes $\mathrm{Hg}$ -
SA and Hg-ST presented better antibacterial activity against Escherichia coli than the corresponding ligands.

\section{ACKNOWLEDGEMENTS}

We thank the National University of Rosario and its Research Council (CIUNR) for financial support, and Prof. M. González-Sierra for useful comments.

\section{REFERENCES}

1. Mandell, G.; Sande, M. In Las bases farmacológicas de la terapéutica; Goodman, A.; Gilman, L., eds.; $6^{\text {th }}$ ed., Ed. Médica Panamericana: Buenos Aires, 1981, cap. 49.

2. Muñoz, C. In Farmacología; Mardones, J., ed.; Intermédica: Buenos Aires, 1979, cap. 60.

3. Blasco, F.; Perelló, L.; Latorre, J.; Borrás, J.; Garciá-Granda, S. J.; Inorg. Biochem. 1996, 61, 143.

4. Ferrer, S.; Borrás, J.; Garcia-España, E.; J. Inorg. Biochem. 1990, 39, 297.

5. Supuran, C. T.; Mincione, F.; Scozzafava, A.; Briganti, F.; Mincinone, G.; Ilies, M. A.; Eur. J. Med. Chem. 1998, 33, 247.

6. Supuran, C. T.; Scozzafava, A.; J. Enzyme Inhib. 1997, 13, 37.

7. Jitianu, A.; Ilies, M. A.; Scozzafava, A.; Supuran, C. T.; Main Group Met. Chem. 1997, 20, 147

8. Scozzafava, A.; Menabuoni, L.; Mincione, F.; Briganti, F.; Mincinone, G.; Supuran, C. T.; J. Med. Chem. 1999, 42, 2641.

9. García-Raso, A.; Fiol, J. J.; Rigo, S.; López-López, A.; Molins, E.; Espinosa, E.; Borrás, E.; Alzuet, G.; Borrás, J.; Castiñeiras, A.; Polyhedron 2000, 19, 991 .

10. Casanova, J.; Alzuet, G.; Ferrer, S.; Borrás, J.; García-Granda, S.; PerezCarreño, E.; J. Inorg. Biochem. 1993, 51, 689.

11. Casanova, J.; Alzuet, G.; Borrás, J.; David, L.; Gatteschi, D.; Inorg. Chim. Acta 1993, 211, 183.

12. Blasco, F.; Perelló, L.; Latorre, J.; Borrás, J.; Garciá-Granda, S.; J. Inorg. Biochem. 1996, 61, 143.

13. García-Raso, A.; Fiol, J. J.; Martorell, G.; López-Zafra, A.; Quirós, M.; Polyhedron 1997, 16, 613.

14. Harvey, S.; ref. 1, cap. 47.

15. Valenzuela, M. I.; Yojay, L.; Solodkowska, W.; ref. 2, cap. 47.

16. Bult, A. In Metal Ions in Byological Systems; Sigel, H., ed.; Marcel Decker: New York, 1983, vol. 16.

17. Harris, D. C.; Bertolucci, M. D.; Symmetry and spectroscopy, NY Oxford University Press, 1978.

18. National Committee for Clinical Laboratory Standard; Performance Standards Antimicrobial Susceptibility Testing, NCCLS Document M100S10, NCCLS 771 East Lancaster Avenue, Villanova, Pensnylvania 19085, USA, 2000

19. Martí, F. B.; Conde, F. L.; Gimerno, S. A.; Méndez, J. H.; Química Analítica Cualitativa, $15^{\text {th }}$ ed., Paraninfo: Madrid, 1994.

20. Fischer, R.; Peters, D.; Compendio de Análisis Químico Cuantitativo, $1^{\text {st }}$ ed., Interamericana: Mexico, 1971.

21. Pretsch, E.; Clerc, T.; Seibl, J.; Simon, W.; Tablas para la elucidación estructural de compuestos orgánicos por métodos espectroscópicos, Alhambra: Madrid, 1985, p. C 120, C 135, C 260, H 260, H 270, H 365.

22. Simó, B.; Perelló, L.; Ortiz, R.; Castiñeira, A.; Latorre, J.; Cantón, E.; J. Inorg. Biochem. 2000, 81, 275.

23. Pasto, D. J.; Johnson, C. R.; Determinación de estructuras orgánicas, Reverté: Barcelona, 1974.

24. Ref. 21, p. I 230.

25. Chufán, E.; Pedregosa, J.; Borrás, J.; Vib. Spectrosc. 1997, 15, 191.

26. Ref. 21, p. U 50.

27. Casas, J. S.; García-Tasende, M.S.; Sordo, J.; Coord. Chem. Rev. 1999, 193 195, 283.

28. Divine, K. K.; Ayala-Fierro, F.; Barber, D. S.; Carter, D. E.; J. Toxicol. Environ. Health, Part A 1999, 57, 489.

29. Popovic, Z.; Matkovic-Calogovic, D.; Soldin, Z.; Pavlovic, G.; Davidovic, N.; Vikic-Topic, D.; Inorg. Chim. Acta 1999, 294, 35.

30. Hu, N-H.; Norifusa, T.; Aoki, K.; Polyhedron 1999, 18, 2987.

31. Gyurcsik, B.; Nagy, L.; Coord. Chem. Rev. 2000, 203, 81.

32. Chan, F. C.; Anward, J.; Cernik, R.; Barnes, P.; Wilson, R.; J. Appl. Crystallogr. 1999, 32, 436.

33. Ref. 1, cap. 48. 